\title{
Bromomethane Contamination in the Cathode of Proton Exchange Membrane Fuel
}

Cells

Yunfeng Zhai ${ }^{\mathrm{a}, *}$, Olga Baturina $^{\mathrm{b}}$, David E. Ramaker ${ }^{\mathrm{b}}$, Erik Farquhar ${ }^{\mathrm{c}}$, Jean St-Pierre ${ }^{\mathrm{a}}$, and Karen E. Swider-Lyons ${ }^{b}$

${ }^{a}$ Hawaii Natural Energy Institute, University of Hawaii, Honolulu, Hawaii 96822, USA.

${ }^{\mathrm{b}}$ Chemistry Division, Naval Research Laboratory, Washington DC 20375, USA.

${ }^{c}$ Case Western Reserve University, Center for Synchrotron Biosciences, Brookhaven National Laboratory, Upton, NY 11973, USA.

\section{Abstract}

The effects of bromomethane $\left(\mathrm{BrCH}_{3}\right)$, an airborne contaminant, on the performance of a single PEMFC are compared with that of another halocarbon, chlorobenzene. Under a constant current of $1 \mathrm{~A} \mathrm{~cm}^{-2}$ and at $45^{\circ} \mathrm{C}, 20 \mathrm{ppm}$ bromomethane causes approximately $30 \%$ cell voltage loss in approximately $30 \mathrm{~h}$, as opposed to much more rapid performance degradation observed with chlorobenzene. Electrochemical impedance spectroscopy, cyclic voltammetry, linear scanning voltammetry, and polarization measurements are applied to characterize the temporary electrochemical reaction effect and permanent performance effects. X-ray absorption spectroscopy is used to confirm that $\mathrm{Br}$ is adsorbed on the Pt electrocatalyst surface. We conclude that airborne bromomethane poisons a PEMFC in a different way from chlorobenzene because it is largely hydrolyzed to bromide, $\mathrm{Br}^{-}$, which is then excluded from the $\mathrm{Pt}$ catalyst by the negatively charged Nafion ionomer. The little $\mathrm{Br}^{-}$and bromomethane that adsorbs on the Pt surface can be partially removed by cycling but causes some irreversible surface area loss.

Keywords: PEM fuel cell, Bromomethane contamination, Cyclic voltammetry, X-ray adsorption fine structure analysis, Donnan exclusion. 


\section{Introduction}

Air pollution has been considered a challenge for the commercialization of proton exchange membrane fuel cells (PEMFCs) due to its detrimental impact on cell performance and durability [1-10]. The atmosphere contains 200 airborne pollutants [11], most of which are volatile organic compounds that can be introduced into the PEMFC cathode compartment. Some of these pollutants physisorb or chemisorb onto the $\mathrm{Pt}$ surface and compete with the crucial oxygen reduction reaction (ORR) [12]. The adsorbed contaminant species can occupy the surface of the platinum electrocatalysts in the PEMFC catalyst layer, reduce the effective electrochemical surface area (ECSA) of the electrocatalyst, and eliminate the ability of the Pt to convert $\mathrm{O}_{2}$ to $\mathrm{H}_{2} \mathrm{O}$ in the kinetically limited ORR. Whereas the physisorbed organic adsorbates can be electro-oxidized or desorbed from the Pt surface simply by exposure to neat (i.e., contaminant-free) air, contaminants such as chloride anions can also undergo irreversible chemical reactions with the platinum. Contaminant cations can exchange with protons in perfluorosulfonic-acid-based proton exchange membranes (PEMs) to increase their resistance and can migrate to the anode electrocatalyst for additional electrocatalyst poisoning.

Recently, twenty-one contaminants were selected for experimentation from more than 150 airborne and indoor detectable pollutants by considering functionality and other factors $[15,16]$. The single-cell performance response to each of these 21 contaminants was investigated under operating conditions that accelerate contamination [16]. The cell performance responses to these contaminants vary with different functionalities. Most of these contaminants can be removed by operating the cell with neat air, and the full or nearly full Pt ECSA can be recovered. This situation is the case for most unsaturated 
hydrocarbons and oxygen-containing hydrocarbon contaminants-e.g., aromatics, alkynes, alkenes, ketones, aldehydes and alcohols (toluene, acetylene, propene, acetone, acetaldehyde and iso-propanol) [16]. However, the cell performance was degraded by more than $50 \%$ with the halocarbon-contaminant bromomethane, and the cell performance loss could not be restored by neat air operation.

Bromomethane, or methyl bromide, is used as a biocide in agriculture; a fumigant for commodity, quarantine treatment, and structural fumigation; and a chemical intermediate and a fire-extinguishing agent. Some bromomethane is formed naturally by algae or kelp in the ocean [17]. Trace amounts of bromomethane have been detected in most places [17]. Industrial areas, fumigated homes and fields have higher levels (ranging up to 1.2 ppb) [17]. Under a moist atmosphere, bromomethane reacts with aluminum, magnesium, zinc, and alloys of these metals, and as a result, bromide may be created $[18,19]$.

The literature indicates that bromomethane and bromide $\left(\mathrm{Br}^{-}\right)$are a poisoning threat to PEMFCs. Under low temperature, low coverages of physisorbed bromomethane tend to lie on the $\operatorname{Pt}(111)$ surface [20]. When bromomethane adsorbs on H-covered $\operatorname{Pt}(111)$, the desorbed products include $\mathrm{CH}_{4}$ and $\mathrm{HBr}$ [21]. Little information exists on the gas-phase or electrochemical adsorption/reaction of bromomethane on Pt catalysts, especially in aqueous acidic environments. Fortunately, the adsorption/reaction of a related species, bromide $\left(\mathrm{Br}^{-}\right)$on a $\mathrm{Pt}$ electrode was studied extensively in aqueous electrolyte [22-28]. The adsorption of bromide on a Pt surface occurs between $0.135 \mathrm{~V}$ and $1.19 \mathrm{~V}$ vs SHE, which covers the PEMFC operating potential ranges [24]. The adsorption of bromide depresses the hydrogen oxidation reaction (HOR) and also significantly impacts the ORR, causing changes in the ORR pathway [24-27]. The bromides desorb below $0.13 \mathrm{~V}$ and were oxidized to bromine $\left(\mathrm{Br}_{2}\right)$ above $1.2 \mathrm{~V}$ [22-24, 27]. 
Our team has previously studied the poisoning effect on PEMFCs of another airborne halocarbon contaminant, chlorobenzene [29]. The results show that chlorobenzene inhibits the ORR and causes significant cell performance loss, but the loss is largely restored by neat air operation and potential cycling. We also found that the chlorobenzene adsorption/reaction and its molecular orientation on the $\mathrm{Pt}$ surface depend on the electrode potential. At low potentials, chlorobenzene deposits either on top of adsorbed $\mathrm{H}$ atoms or on the Pt surface via a benzene ring. At high potentials, the chlorobenzene binds to $\mathrm{Pt}$ via the $\mathrm{Cl}$ atom. $\mathrm{Cl}^{-}$is created and remains in the membrane electrode assembly. $\mathrm{Cl}^{-}$ binds to the Pt surface much more strongly than chlorobenzene but can be slowly flushed out by liquid water.

Similar to chlorobenzene, bromomethane has a halogen moiety that serves as an electron withdrawing functionality. This suggests that bromomethane and chlorobenzene may share similar contamination features, although the methyl group has different adsorption behavior than an aromatic group. The adsorption of dilute $\mathrm{Br}^{-}$, a possible by-product, on $\mathrm{Pt}$ is stronger than that of $\mathrm{Cl}^{-}$in $\mathrm{HClO}_{4}[27,28]$. Therefore, a comparison between these 2 halocarbons might guide the development of the bromomethane contamination mechanism.

In this manuscript, the contamination of PEMFCs with bromomethane-contaminated air is investigated and compared with that of chlorobenzene. Electrochemical impedance spectroscopy (EIS), cyclic voltammetry (CV), linear scanning voltammetry (LSV) and polarization measurements (VI) are applied to characterize the temporary electrochemical reaction effect and the permanent performance loss. X-ray absorption spectroscopy (XAS) is carried out in a spectro-electrochemical cell to identify chemical changes to the Pt and bromomethane and identify the nature of the adsorbates on the Pt. All of these 
characterization results are combined to understand the contamination mechanisms of halocarbons in a PEMFC cathode.

\section{Experimental}

The bromomethane contamination tests were conducted with similar procedures and the same cell design and conditions as for the chlorobenzene contamination study [29]. A FCATS ${ }^{\text {тм }}$ G050 series test station (Green Light Power Technologies Inc.) and a $50 \mathrm{~cm}^{2}$ single cell (double and triple serpentine flow field channels machined on graphite plates for the anode and cathode, respectively) were used. The membrane electrode assemblies (MEAs) were purchased from Gore (GORE® PRIMEA® M715 catalyst coated

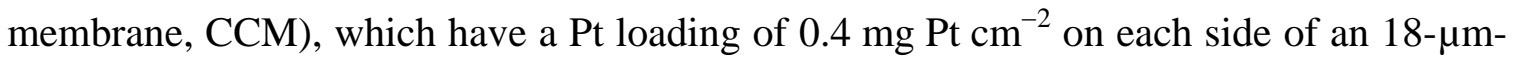
thick Nafion-XL membrane. The cells were assembled with 25 BC gas diffusion layers (GDL, SGL Tech.) for both the anode and the cathode. The cells were operated at $45^{\circ} \mathrm{C}$ with $2 / 2$ flow stoichiometry and $100 / 50 \%$ relative humidity for the anode and cathode respectively. The outlet back pressures were $10 / 10 \mathrm{kPag}$, corresponding to a dry reactant pressure of 1 atm at the cell operating temperature. The bromomethane concentration in the cathode reactant stream was $20 \mathrm{ppm}$. The gas mixture was supplied by Matheson Tri-Gas Inc. and contained 400-ppm bromomethane in air. The constant current tests

(CChold) were conducted at $1 \mathrm{~A} \mathrm{~cm}^{-2}$ in three phases: pre-poisoning, poisoning and self-induced performance recovery.

During the constant current tests, EIS data were obtained using a Solartron SI1260 Impedance/Gain-Phase Analyzer $(0.1 \mathrm{~Hz}$ to $10 \mathrm{kHz}, 10$ points per decade), a Stanford Research SR560 Low Noise Preamplifier and ZPlot® (Scribner Associates) software. An alternating current perturbation of $0.75 \mathrm{~A}$ was applied to the single cell, which resulted in a voltage change of approximately $5 \mathrm{mV}$. The VI curves were obtained with $\mathrm{H}_{2} / \mathrm{Air}$. LSV 
and $\mathrm{CV}$ tests were completed with $\mathrm{H}_{2} / \mathrm{N}_{2}$, before and after contamination experiments. The V-I curves were measured from high currents to the open circuit voltage (OCV) with a stabilization time of $15 \mathrm{~min}$ at each current and operating condition, similar to those of constant current tests. $\mathrm{CV}$ was completed at $35^{\circ} \mathrm{C}$ with saturated hydrogen at the reference electrode and nitrogen at the working electrode and a flow rate of $0.466 \mathrm{~L} \mathrm{~min}^{-1}$. A total of 10 scans were executed with a scan rate of $20 \mathrm{mV} \mathrm{s}^{-1}$ and a potential range of 0.08 to $1.2 \mathrm{~V}$ vs. the hydrogen reference electrode (HRE).

XAS experiments were performed with similar procedures as for the chlorobenzene contamination study, on the X3A beamline at the National Synchrotron Light Source at Brookhaven National Laboratory [29]. A Si(220) monochromator with sagittal focusing of the second crystal was used with a downstream Pd-coated cylindrically bent mirror providing vertical focusing and harmonic rejection. The $\mathrm{X} 3 \mathrm{~A}$ beamline was equipped with a flexible sample stage in which a custom-made spectro-electrochemical cell was mounted. The beam was focused to a $1-\mathrm{mm}^{2}$ spot size at the sample. The Pt LIII edge spectra were acquired in fluorescence mode using a 13-element Canberra germanium fluorescence detector by scanning the incident energy between 11400 and $12400 \mathrm{eV}$. A Pt foil was used as a reference to ensure proper instrument calibration with the $\mathrm{Pt} \mathrm{L}_{3}$ absorption edge set to $11564 \mathrm{eV}$. When necessary, $\mathrm{Zn}$ filters were placed between the sample and germanium detector to reduce scattering photons and ensure that the $\mathrm{Ge}$ detector counts were in the linear region $(<100 \mathrm{kHz})$. A spectro-electrochemical cell [29] was assembled with a CCM (50 wt \% Pt/C, 0.4/0.4 mg Pt cm ${ }^{-2}$, Nafion 212, $10 \mathrm{~cm}^{2}$ coated area, Ion Power, Inc.) and a carbon cloth GDL (E-TEK). The E-TEK carbon cloth was soaked in a $0.1 \mathrm{M} \mathrm{HClO}_{4}$ solution. One side of the CCM was connected to a current collector (Au foil) and served as a working electrode (WE), whereas the other side was connected to a Pt wire serving as a counter electrode (CE). The WE was examined with 
$\mathrm{N}_{2}$ and then after supplying 500-ppm bromomethane in synthetic air (Alfa-zero, Air Liquide) for 40 min. A no-leak $\mathrm{Ag} / \mathrm{AgCl}$ electrode (Cypress Systems, Inc.) is mounted in the CE compartment. A potential of $0.6 \mathrm{~V}$ vs. the $\mathrm{HRE}$ in $0.1 \mathrm{M} \mathrm{HClO}_{4}$ solution was applied on the WE while purging the WE chamber either with $\mathrm{N}_{2}$ or bromomethane in air.

\section{Results}

\subsection{Cell Performance Degradation and Recovery}

Figure 1 shows the cell voltage degradation due to exposure of the PEMFC cathode to 20-ppm bromomethane and the self-recovery upon re-exposure to neat air while holding at constant current, followed by $\mathrm{CV}$ and polarization curves at the end of the experiment. The results for chlorobenzene CChold with final CV/VI are included for a comparison. For the first $5 \mathrm{~h}$ under neat $\mathrm{H}_{2} /$ Air operation, all cells show an identical voltage of $0.66 \mathrm{~V}$

at $1 \mathrm{~A} \mathrm{~cm}^{-2}$. When bromomethane is introduced into the airstream, the cell voltage slowly decays until the bromomethane exposure is stopped at either $8 \mathrm{~h}$ or $30 \mathrm{~h}$ of exposure. The voltage curve for the $8 \mathrm{~h}$ exposure overlaps with the curve for the $30 \mathrm{~h}$ exposure, confirming the repeatability of the contamination experiments. The cell voltage decreases by approximately $0.06 \mathrm{~V}$ and $0.2 \mathrm{~V}$ during $8 \mathrm{~h}$ and $30 \mathrm{~h}$ bromomethane exposures, respectively, indicating that bromomethane poisons the electrode and the poisoning extent depends on the exposure time. By comparison, chlorobenzene leads to a $0.51-\mathrm{V}$ drop within $20 \mathrm{~min}$, a significantly more rapid process than for bromomethane. It is not possible to obtain a longer chlorobenzene exposure test of $30 \mathrm{~h}$ because the load bank does not properly function for a cell voltage lower than $\sim 60 \mathrm{mV}$.

Upon exposure to neat air, the bromomethane-poisoned MEAs undergo some self-recovery and show identical voltage gains regardless of whether poisoned for 8 or 30 
h. This self-recovery restores the cell voltage to a level equivalent to $94 \%(0.62 \mathrm{~V})$ and $77 \%(0.51 \mathrm{~V})$ of the initial performance for the $8 \mathrm{~h}$ and the $30 \mathrm{~h}$ bromomethane exposure experiments, respectively.

Additional recovery is induced by the final diagnostic measurements, consisting of a $\mathrm{CV}$ scan and measurement of the cell polarization curve. These last measurements improve the voltage from $77 \%$ to $94 \%$ of the initial voltage for the MEA exposed to bromomethane for $30 \mathrm{~h}$. Furthermore, it is noted that $0.1-0.3 \mathrm{ppm}$ of bromides were detected in the effluent water of a poisoned cell by ion chromatography during similar bromomethane contamination tests completed with different operating conditions. The low potential applied during the CV scan and the liquid water created at high current densities play an important role for the desorption of anions from the MEA, as previously observed for air electrodes contaminated by chlorobenzene [29], sulfuric compounds $\left(\mathrm{SO}_{4}{ }^{2-}\right)$ [8], and $\mathrm{HCl}\left(\mathrm{Cl}^{-}\right)$[9]. The lower positive potential on the cathode allows desorption of the negatively charged $\mathrm{Br}^{-}$from the Pt surface, and the liquid water carries the bromides away from the catalyst layer.

\subsection{Electrochemical Impedance Spectroscopy Analysis}

EIS spectra collected during the contamination experiments provide more information about how bromomethane poisoning affects fuel cell reactions. Figure 2(a) shows the representative impedance spectra in Nyquist coordinates after different periods of CChold. All spectra show the expected features at high current densities with three distinguishable depressed semicircles [30]. The high-frequency intercept with the $\mathrm{x}$-axis is indicative of the PEM resistance. The high-frequency $(>1 \mathrm{kHz})$ capacitive response is attributed to the hydrogen oxidation reaction (HOR) at the anode; the mid-range frequency $(5-1 \mathrm{kHz})$ response is attributed to the ORR at the cathode and the low frequency $(0.1-5 \mathrm{~Hz})$ 
response to mass transport in the gas diffusion electrode (GDE). For the mid- and low-frequency responses, variations are observed between different periods of the contamination experiment. After $10 \mathrm{~h}$ of exposure, both impedance loops slightly shrink, whereas after $30 \mathrm{~h}$ of exposure, both loops expand and are subsequently and partially restored after self-recovery. After CV scans and polarization curve measurements, both mid- and low-frequency loops are finally restored to their original state. It is also noted that an inductive loop is not observed. By contrast, in the poisoning experiments with chlorobenzene or acetylene, an inductive loop occurs due to the reduction of the chlorobenzene aromatic ring or acetylene [29, 31].

With the absence of an inductive loop, the impedance parameters associated with the ORR can be derived from EIS spectra in Figure 2(a) by fitting them with an equivalent circuit model previously validated for $\mathrm{SO}_{2}$ contamination [30]. Figure 2(b) shows the results for the ohmic resistance (Ro), anode charge transfer resistance (Ra), cathode charge transfer resistance $(\mathrm{Rc})$ and cathode gas diffusion resistance $(\mathrm{Rd})$. The constant Ro values indicate that bromomethane has no effect on the membrane conductivity. However, there is an approximate $23 \%$ increase in $\mathrm{Ra}$ after approximately $3 \mathrm{~h}$ of bromomethane exposure, suggesting that bromomethane or one of its decomposition products permeates to the anode side and negatively affects the HOR. The contaminant species appears to stay in the anode catalyst layer even after CV and polarization measurements. The most significant change in the resistance parameters is observed in $\mathrm{Rc}$ and $\mathrm{Rd}$. Rc decreases by approximately $10 \%$ within the first $15 \mathrm{~h}$ of bromomethane exposure and then increases by $10 \%$ over its initial value at the end of the $30 \mathrm{~h}$ of exposure. A similar variation in $\mathrm{Rc}$ has been observed in $\mathrm{SO}_{2}$ contamination of a PEMFC and is attributed to the poisoning effect of this contaminant on the ORR [30]. Anions created in the catalyst layer adsorb on the Pt surface and modify the oxygen reduction 
reaction pathway [30]. Anion adsorption is expected to increase the kinetic resistance $\mathrm{R}_{\mathrm{c}}$. However, ORR pathway changes induced by anion adsorption are also possible, which would shrink the mid-frequency loop [30]. Figure 2(b) observations are consistent with this dual and opposite impact of contamination characterized by different time scales [30]. In Figure 2(b), at the start of the contaminant exposure, there is a progressive increase in Rd until it exceeds $50 \%$ of the initial value. This significant Rd increase suggests bromide accumulation at the interface between the ionomer film and the Pt surface.

The resistance parameters in Figure 2(b) also confirm that the self-recovery and $\mathrm{CV} /$ polarization curve steps restore the impedance response of the MEA, as bromides are desorbed during the low potential portion of $\mathrm{CV}$ scans and the water produced during polarization measurements at high currents flushes them away from the catalyst layer (as discussed above).

\subsection{MEA Performance Characterizations-CV, LSV and VI}

Figure 3 shows the $\mathrm{CV}$ profiles of the MEA cathode (Ec) and anode (Ea) before (BOT) and after (EOT) the bromomethane contamination experiments. The beginning of test CVs, both EcBOT and EaBOT, show typical Pt/C features. However, both cathode and anode EOT CVs show similar features, with diminished features in the hydrogen and oxygen regions of the $\mathrm{CVs}$ reminiscent of $\mathrm{Pt}$ with surface sites poisoned, preventing water activation. For both the cathode and anode, exposure to $8 \mathrm{~h}$ of bromomethane-contaminated air causes the hydrogen oxidation/reduction current peaks at $0.10-0.40 \mathrm{~V}$ to decrease and shift to lower potentials. Bromomethane poisoning also causes the onset of the Pt oxidation and reduction peaks to shift to higher potentials, and their current to decrease. This indicates that $\mathrm{CV}$ scans have no effect on the bromomethane-contaminated electrode surfaces. After $30 \mathrm{~h}$ of exposure to bromomethane, 
the changes in the $\mathrm{CV}$ are more pronounced for hydrogen oxidation/reduction current peaks $(<0.35 \mathrm{~V})$ and $\mathrm{Pt}$ oxidation/reduction current peaks $(>0.6 \mathrm{~V})$. Additionally, a significant oxidation current peak appears at approximately $0.08 \mathrm{~V}$. All noted CV changes agree well with bromide adsorption on a Pt surface in aqueous acid solutions and loss of water activation sites [22-27]. The anode curves in Figure 3(b) confirm the EIS analysis, also depicting an effect of bromomethane on the HOR.

The losses in ECSA are shown in Figure 3(c) as calculated from the area under the hydrogen reduction current peak in Figures 3(a) and 3(b). After the $8 \mathrm{~h}$ of 20-ppm bromomethane contamination in the airstream, the cathode and anode lose approximately $27.7 \%$ and $22.5 \%$ of their ECSA, respectively. After $30 \mathrm{~h}$ of such contamination, the cathode and anode lose approximately $37.9 \%$ and $30.4 \%$ of their ECSA, respectively. By comparison, after 3-h of 20-ppm chlorobenzene contamination experiments, the ECSA loss is much smaller for both the cathode (11.4\%) and the anode (2.7\%), although the voltage loss is much higher (see Figure 1). The cathode loss is partially regained by CV scan with a loss reduced to $3.2 \%$ [29]. For this chlorobenzene test, the slight catalyst degradation of approximately 3\% ECSA is attributed to the growth and corrosion of Pt particles and some leftover electro-inactive species such as chloride [9, 29]. For the bromomethane tests, the irrecoverable ECSA loss (Figure 3) may also be attributed to some Pt growth and corrosion processes and leftover electro-inactive bromide. The larger ECSA loss caused by bromomethane implies that bromides show a larger ECSA effect than chlorides, an observation that is consistent with literature reports $[32,33]$.

Before and after the contamination experiment, the MEA hydrogen crossover is also measured by LSV. The oxidation current density of hydrogen diffusing through the MEAs is used to calculate the hydrogen crossover. The current densities before and after the experiment show a similar value of $\sim 1.1 \mathrm{~mA} \mathrm{~cm}^{-2}$, as shown in Figure 4 . These 
results indicate that bromomethane contamination has no obvious effect on the permeability of the membrane.

The polarization curves (VI) collected from $1.2 \mathrm{~A} \mathrm{~cm}^{-2}$ to $\mathrm{OCV}$ before and after contamination are shown in Figure 5. The inset depicts the kinetic region in Tafel coordinates, which are obtained by $\mathrm{H}_{2}$ crossover and HFR-corrected VI curves within a current density range of 0.01 to $0.1 \mathrm{~A} \mathrm{~cm}^{-2}$. Beyond the kinetic region where the current density is higher than $0.1 \mathrm{~A} \mathrm{~cm}^{-2}$, the voltage decreases by approximately $15 \mathrm{mV}$ and $30 \mathrm{mV}$ after $8 \mathrm{~h}$ and $30 \mathrm{~h}$ of exposure to bromomethane poisoning, respectively. All polarization curves show a similar Tafel slope of $\sim 70 \mathrm{mV}$ per decade, which confirms the absence of active adsorbates (as opposed to simple poisons that would only reduce the active surface area) on the electrode surface. The $23 \mathrm{mV}$ difference for the $8 \mathrm{~h}$ exposure test $(31 \mathrm{mV}$ for the $30 \mathrm{~h}$ test) is attributed to the irrecoverable ECSA loss and perhaps also to the adsorption of certain leftover electro-inactive species, such as bromide created during bromomethane contamination. These results suggest that a permanent kinetic effect remains after neat air operation, CV scan and polarization curve recovery. A larger and permanent kinetic loss results from a longer bromomethane contamination.

\subsection{XANES analysis of Bromomethane adsorption on a Pt surface}

The X-ray absorption near edge structure (XANES) results for the Pt LIII edge of an in situ CCM are shown in Figure 6 under 3 conditions: OCV, $0.6 \mathrm{~V}$ in neat air and after 40 min of exposure to $500 \mathrm{ppm}$ bromomethane in air at $0.6 \mathrm{~V}$. This higher-dose, shorter-duration exposure is used to expedite the experiments for expensive beamline time. The CV results of the poisoning of the MEA in the spectro-electrochemical cell are consistent with those observed for the MEA on the standard test stand, with CVs showing suppression of the hydrogen and oxygen regions after poisoning. 
As expected, the Pt white line near $11,570 \mathrm{eV}$ decreases as the cell is changed from OCV to operation at $0.6 \mathrm{~V}$ and the Pt oxide scale on the nanoparticulate catalysts is reduced [34]. When exposed to the $500 \mathrm{ppm}$ of bromomethane for $40 \mathrm{~min}$, there is no reduction of the Pt white line, suggesting no qualitative change in the Pt oxidation state. There are also no extra peaks for $\mathrm{Pt}^{2+}$, as would occur if platinum bromide $\left(\mathrm{PtBr}_{2}\right)$ had formed. The overlay of the results for the clean and contaminated sample also indicates that bromomethane contamination does not cause Pt particle growth, as has been observed with $\mathrm{HCl}$ poisoning [9]. For the $\mathrm{HCl}$ contamination work, the electrode was exposed for $24 \mathrm{~h}$ at $80^{\circ} \mathrm{C}$. However, for the present XAS experiment, the electrode was exposed to bromomethane for only $40 \mathrm{~min}$ at room temperature. The absence of $\mathrm{Pt}$ particle growth is attributed to that shorter exposure and lower temperature. Additionally, the XANES results at the $\mathrm{Br} \mathrm{K}$ edge $(\sim 13,480 \mathrm{eV})$ identify the $\mathrm{Br}$ species on the electrode surface after poisoning and purging.

To further examine the Pt XANES results, we apply the $\Delta \mu$ methodology. We have used this approach successfully to determine the species and site adsorption of contaminants including $\mathrm{SO}_{2}$ [35] and chlorobenzene [29]. Figure 7 shows the $\Delta \mu$ XANES results at $0.6 \mathrm{~V}$ after exposure to $500-\mathrm{ppm}$ bromomethane in air for $40 \mathrm{~min}$. The $\Delta \mu$ signal from the adsorbate is very weak, suggesting that only a small amount of the poison has reached the Pt electrode (consistent with the electrochemical data in Figure 1).

As described in the chlorobenzene contamination paper [29], the theoretical X-ray adsorption spectra $\mu_{\text {theo }}$ on a small $\mathrm{Pt}_{6}$ cluster was obtained to model the Pt surface by calculating the full multiple scattering. The difference, $\Delta \mu_{\text {theo }}$ was obtained with the $\mathrm{Br}$ in either an atop, bridged, or 3-fold site, giving three significantly different $\Delta \mu$ signatures as 


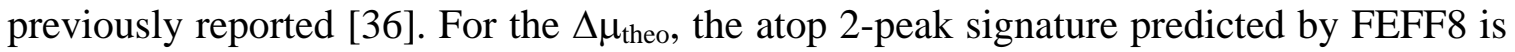
quite unique and was also experimentally obtained [36].

The $\Delta \mu$ results from the spectro-electrochemical cell at $0.6 \mathrm{~V}$ match the calculated bromide/Pt signature in the atop position (in Figure 7). These data suggest that bromomethane adsorbs in a configuration with the $\mathrm{Br}$ atom bonded to the $\mathrm{Pt}$ surface with the methyl group above it or as bromide on the catalyst surface. These configurations yield the same signature (atoms not bound to the surface do not contribute significantly to the $\Delta \mu$ signal). All results obtained with a single cell confirm that bromide is the poisoning species in contact with the platinum during PEMFC contamination by bromomethane.

\section{Discussion}

PEMFCs exposed to $20 \mathrm{ppm}$ of bromomethane in the airstream undergo relatively slow voltage loss compared with chlorobenzene. The potential loss of the PEMFC is only $0.06 \mathrm{~V}$ and $0.2 \mathrm{~V}$ after $8 \mathrm{~h}$ and $30 \mathrm{~h}$ of exposure to 20 -ppm bromomethane, whereas there is a $0.51 \mathrm{~V}$ loss after $20 \mathrm{~min}$ of exposure to 20-ppm chlorobenzene in a similar test cell. This result is surprising considering that adsorption of bromide is stronger than that of chloride on the Pt surface $[27,28]$, and there is a strong corrosion effect of halogen ions on $\mathrm{Pt}[9,37]$.

The reason for this relative lack of poisoning by bromomethane is not immediately clear. The electrocatalysts poisoned for $30 \mathrm{~h}$ with bromomethane show higher irreversible cell performance losses after $\mathrm{CV}$ and polarization curves in neat air, suggesting either loss of the Pt electrocatalyst. However, the X-ray absorption results show no strong evidence for the formation for $\mathrm{PtBr}_{2}$. 
Further, $\Delta \mu$ analysis of the XAS results show that when the cell is held at $0.6 \mathrm{~V}$, a small amount of bromomethane is adsorbed on the Pt with the halide in an atop position on the Pt surface, the same configuration as observed for chlorobenzene. The combination of results indicates that bromomethane and chlorobenzene poison $\mathrm{Pt}$ in the same way, but far less bromomethane is available at the Pt interface.

A similar lag in poisoning has been observed by 4-ppm airborne $\mathrm{HCl}$ poisoning, which was attributed to exclusion of the $\mathrm{Cl}^{-}$ions by the negatively charged Nafion ionomer, or Donnan exclusion. Therefore, the poisoning of bromomethane is more similar to that of airborne $\mathrm{HCl}$ than chlorobenzene, suggesting that $\mathrm{Br}^{-}$is the main contaminant.

Halogen compounds can be easily hydrolyzed by water in alkaline solutions; the consumption of products also can force the hydrolysis process through the acidic environment in the catalyst layer of MEA. With consideration of the hydrolysis reactions of bromomethane in the oxidative cathode environment, the possible contamination mechanisms are proposed, as illustrated in Figure 8a. Bromomethane may be hydrolyzed to bromide and methanol before reaching the Pt electrode; bromomethane may also permeate through the ionomer film and be hydrolyzed on the Pt electrode, via reaction (1):

$$
\mathrm{CH}_{3} \mathrm{Br}+\mathrm{H}_{2} \mathrm{O} \leftrightarrow \mathrm{CH}_{3} \mathrm{OH}+\mathrm{H}^{+}+\mathrm{Br}^{-}
$$

The created methanol is oxidized readily on the Pt surface with reactions (2-4):

$$
\begin{gathered}
\mathrm{CH}_{3} \mathrm{OH}+3 / 2 \mathrm{O}_{2} \underset{P t}{\leftrightarrow} 2 \mathrm{H}_{2} \mathrm{O}+\mathrm{CO}_{2} \\
\mathrm{CH}_{3} \mathrm{OH}+6 \mathrm{HO}^{\cdot} \underset{P t}{\leftrightarrow} 5 \mathrm{H}_{2} \mathrm{O}+\mathrm{CO}_{2}
\end{gathered}
$$




$$
\mathrm{CH}_{3} \mathrm{OH}+\mathrm{H}_{2} \mathrm{O} \underset{P t}{\leftrightarrow} \mathrm{CO}_{2}+6 \mathrm{H}^{+}+6 e
$$

Because of the Donnan exclusion, the bromides outside the film cannot access the Pt surface, but those created at the interface of the ionomer film and Pt surface are difficult to remove. The hydrolysis of bromomethane consumes part of bromomethane before it reaches the Pt surface, resulting in a slow poisoning process. For chlorobenzene, the hydrolysis is not the case because of the stability of the hydrolysis product and phenols in the cathode environment.

This hypothesis is supported by the EIS results, which show that the parameters most affected by the poisoning are the cathode charge-transfer resistance $(\mathrm{Rc})$ and cathode gas-diffusion resistance (Rd). After the bromomethane reaches the catalyst, its hydrolysis yields $\mathrm{Br}^{-}$ions that become trapped at the interface because they cannot penetrate the ionomer (Donnan exclusion). The accumulation of bromomethane increases the liquid water content at the film/Pt interface by osmosis, increasing the diffusion distance for oxygen. This behavior was observed during $\mathrm{SO}_{2}$ contamination of the cathode, where $\mathrm{SO}_{4}{ }^{2-}$ was created at the ionomer film and Pt surface interface [30]. Regarding the recovery, bromides are desorbed during the low potential portion of $\mathrm{CV}$ scans, and the water produced during polarization measurements at high currents flushes them away from the catalyst layer. As a result, $\mathrm{Rd}$ is restored to its initial value. It is emphasized that the mechanism by which $\mathrm{Br}^{-}$ions move away from the ionomer/Pt interface to reach liquid water is unclear (perhaps surface diffusion on Pt or C). This process is likely dependent on the potential because recovery is observed only if low cathode potentials are combined with the presence of liquid water (not shown). It was previously shown that 
bisulfate $\left(\mathrm{SO}_{4}{ }^{2-}\right)$ and $\mathrm{Cl}^{-}$desorb from $\mathrm{Pt}$ at low potentials where there is less electrostatic attraction between the cathode and adsorbed anions [9, 38].

Regarding the potential dependency of bromomethane/bromide adsorption on a $\mathrm{Pt}$ surface, the XANES analysis of bromomethane and chlorobenzene implies identical mechanisms for adsorption of these two species on Pt within a normal cell operating in a potential range-e.g., above $0.3 \mathrm{~V}$. However, the effect on cell performance is different because the adsorbate orientation is different. As illustrated in Figure 8b, during bromomethane and bromide adsorption, the $\mathrm{Br}$ atom is in contact with the $\mathrm{Pt}$ surface within the entire cathode potential range (0-1 V vs SHE). However, for chlorobenzene, the aromatic ring is lying on the Pt surface at low cathode potentials below $0.3 \mathrm{~V}$ vs SHE. When the applied potential is near or lower than the potential at the point of zero charge, both bromomethane/bromide and chloride desorb from Pt surface and can be removed by liquid water in the catalyst layer.

\section{Conclusion}

The 20-ppm bromomethane exposure causes approximately $30 \%$ of cell voltage loss, but only after $30 \mathrm{~h}$ exposure. The loss can be partially recovered up to $77 \%$ by neat air operation and up to $94 \%$ by CV cycling and polarization measurement. Bromomethane and/or its product bromide adsorb on the cathode and anode and depress both ORR and HOR.

The bromomethane appears to break down to $\mathrm{Br}^{-}$, which accumulates at the catalyst layer interface due to Donnan exclusion by the Nafion ionomer and inhibits mass transport processes. The catalyst surface then becomes covered with the bromide, which cannot be removed by $\mathrm{CV}$ scanning alone. Polarization curves show some permanent performance loss within the Tafel range after performance recovery, which may be 
attributed to the effect of leftover bromide and Pt dissolution and particle growth. However, the low potential applied during the CV scanning induces bromide desorption from Pt sites, and liquid water flushes the desorbed bromide out of the catalyst layer.

We conclude that poisoning by air contaminants remains an important research area because species that are apparently similar, chlorobenzene and bromomethane, have dissimilar responses in the PEMFC environment as well as from what is expected from liquid half-cell experiments. Future experiments with $\mathrm{Br}_{2}$ and $\mathrm{HBr}$ contaminants might further refine the bromomethane contamination mechanism.

\section{Acknowledgments}

The authors are grateful to the United States Department of Energy (award DE-EE0000467) and the Office of Naval Research (award N00014-13-1-0463) for financial support of this project. The authors are grateful to the Hawaiian Electric Company for their ongoing support to the operations of the Hawaii Sustainable Energy Research Facility. XAS data were collected on beamline X3A of the National Synchrotron Light Source, which was supported by the National Institutes of Health (P30-EB-009998) and US Department of Energy, Office of Science (Contract No. DE-AC02-98CH10886). 


\section{References}

[1] R. Borup, J. Meyers, B. Pivovar, Y. Kim, R. Mukundan, N. Garland, D. Myers, M. Wilson, F. Garzon, D. Wood et al., Scientific aspects of polymer electrolyte fuel cell durability and degradation, Chem. Rev. 107 (2007) 3904.

[2] M. Debe, Electrocatalyst approaches and challenges for automotive fuel cells, Nature 486 (2012) 43.

[3] J. St-Pierre, Air impurities, in: Büchi FN, Inaba M, Schmidt TJ (Eds.), Polymer electrolyte fuel cell durability, Springer, New York, 2009, pp. 289.

[4] X. Cheng, Z. Shi, N. Glass, L. Zhang, D. Song, Z. Liu, H. Wang, J. Shen, A review of PEM hydrogen fuel cell contamination: impacts, mechanisms, and mitigation, J. Power Sources 165 (2007) 739.

[5] J. Moore, P. Adcock, J. Lakeman, G. Mepsted, The effects of battlefield contaminants on PEMFC performance, J. Power Sources 85 (2000) 254.

[6] R. Mohtadi, W. Lee, J.W. Van Zee, Assessing durability of cathodes exposed to common air impurities, J. Power Sources 138 (2004) 216.

[7] H. Li, J. Zhang, Z. Shi, D. Song, K. Fatih, Sh. Wu, H. Wang, J. Zhang, N. Jia, S. Wessel, et al., PEM fuel cell contamination: effects of operating conditions on toluene-induced cathode degradation, J. Electrochem. Soc. 156 (2009) B252.

[8] Y. Garsany, O. Baturina, K. Swider-Lyons, Impact of sulfur dioxide on the oxygen reduction reaction at Pt/Vulcan carbon electrocatalysts, J. Electrochem. Soc. 154 (2007) B670.

[9] O. Baturina, A. Epshteyn, P. Northrup, K. Swider-Lyons, Insights into PEMFC performance degradation from $\mathrm{HCl}$ in air, J. Electrochem. Soc. 158 (2011) B1198. 
[10]N. Zamel, X. Li, Effect of contaminants on polymer electrolyte membrane fuel cells, Prog. Energy Combust. Sci. 37 (2011) 292.

[11]Air Quality Statistics Report, United States Environmental Protection Agency, AirData Home page: Access to monitored air quality data from EPA's Air Quality System data Mart, http://www.epa.gov/airquality/airdata/index.html (accessed August 2015).

[12]Z. Ma, F. Zaera, Organic chemistry on solid surfaces, Surf. Sci. Rep. 61 (2006) 229.

[13]J. St-Pierre, PEMFC contaminant tolerance limit - foreign cations in ionomers, Int. J. Hydrogen Energy 36 (2011) 5527.

[14]J. St-Pierre, PEMFC contamination model: foreign cation exchange with ionomer protons, J. Power Sources 196 (2011) 6274.

[15]J. St-Pierre, Y. Zhai, M. Angelo, Quantitative ranking criteria for PEMFC contaminants, Int. J. Hydrogen Energy 37 (2012) 6784.

[16]J. St-Pierre, Y. Zhai, M. Angelo, Effect of selected airborne contaminants on PEMFC performance, J. Electrochem. Soc. 161 (2014) F280, and 162 (2015) X7.

[17]Agency for Toxic Substances and Disease Registry (ATSDR), Toxicological profile for bromomethane, U.S. Public Health Service, U.S. Department of Health and Human Services, Atlanta, GA, 1992.

[18]D. Hartley, H. Kidd (Eds.), The Agrochemicals Handbook (2nd Ed) Lechworth, Herts, England: The Royal Society of Chemistry, 1987, p. A273/Aug 87.

[19]Kirk-Othmer, Encyclopedia of Chemical Technology (4th Ed) Vol. 1: New York, NY. John Wiley and Sons, 1991-Present, p. V4 (1992) 568.

[20] T. Schwendemann, I. Samanta, T. Kunstmann, I. Harrison, $\mathrm{CH}_{3} \mathrm{Br}$ structures on $\operatorname{Pt}(111)$ : kinetically controlled self-assembly of weakly adsorbed dipolar molecules, J. Phys. Chem. C 111 (2007) 1347. 
[21]S. Wehner, J. Küppers, Interaction of gaseous D atoms with alkyl halides adsorbed on $\mathrm{Pt}(111), \mathrm{H} / \mathrm{Pt}(111)$, and $\mathrm{C} / \mathrm{Pt}(111)$ surfaces: Hot-atom and Eley-Rideal reactions. I. Methyl bromide, J. Chem. Phys. 111 (1999) 3209.

[22]S. Ferro, A. De Battisti, The bromine electrode. Part I: adsorption phenomena at polycrystalline platinum electrodes, J. Appl. Electrochem. 34 (2004) 981.

[23]J. Xu, N. Georgescu, D. Scherso, The oxidation of bromide on platinum electrodes in aqueous, acidic solutions: electrochemical and in situ spectroscopic studies, J. Electrochem. Soc. 161 (2014) H392.

[24]D. Trinh, M. Keddam, X. Nóvoa, V. Vivier, Characterization of adsorbates by transient measurements in scanning electrochemical microscopy, Electrochim. Acta 131 (2014) 28.

[25]N. Marković, H. Gasteiger, B. Grgur, P. Ross, Oxygen reduction reaction on Pt(111): effects of bromide, J. Electroanal. Chem. 467 (1999) 157.

[26]N. Marković, C. Lucas, H. Gasteiger, P. Ross, Bromide adsorption on Pt(100): rotating ring-Pt(100) disk electrode and surface X-ray scattering measurements, Surf. Sci. 365 (1996) 229.

[27]M. Breiter, Voltammetric study of the reduction of molecular oxygen on platinum in perchloricacid solutions, Electrochim. Acta 8 (1963) 925.

[28]N. Marković, P. Ross, Surface science studies of model fuel cell electrocatalysts, Surf. Sci. Rep. 45 (2002) 117.

[29] Y. Zhai, O. Baturina, D. Ramaker, E. Farquhar, J. St-Pierre, K. Swider-Lyons, Chlorobenzene poisoning and recovery of platinum-based cathodes in proton exchange membrane fuel cells, J. Phys. Chem. C 119 (2015) 20328. 
[30] Y. Zhai, K. Bethune, G. Bender, R. Rocheleau, Analysis of the $\mathrm{SO}_{2}$ contamination effect on the oxygen reduction reaction in PEMFCs by electrochemical impedance spectroscopy. J. Electrochem. Soc. 159 (2012) B524.

[31] Y. Zhai, J. St-Pierre, Proton exchange membrane fuel cell cathode contamination acetylene, J. Power Sources 279 (2015) 165.

[32]M. Teliska, V. Murthi, S. Mukerjee, D. Ramaker, Site-specific vs specific adsorption of anions on Pt and Pt-based alloys. J. Phys. Chem. C 111 (2007) 9267.

[33] T. Arruda, B. Shyam, J. Ziegelbauer, S. Mukerjee, D. Ramaker, Investigation into the competitive and site-specific nature of anion adsorption on Pt using in situ X-ray absorption spectroscopy. J. Phys. Chem. C 112 (2008) 18087.

[34]S. Mukerjee, J. McBreen, Effect of particle size on the electrocatalysis by carbon-supported Pt electrocatalysts: an in situ XAS investigation, J. Electroanal. Chem. 448, (1998) 163.

[35]D. E. Ramaker, D. Gatewood, A. Korovina, Y. Garsany, K. E. Swider-Lyons, Resolving sulfur oxidation and removal from $\mathrm{Pt}$ and $\mathrm{Pt}_{3} \mathrm{Co}$ electrocatalysts using in situ X-ray absorption spectroscopy, J. Phys. Chem. C 114 (2010) 11886.

[36]M. Farmand, X-ray absorption spectroscopy characterization of electrochemical processes in renewable energy storage and conversion devices. Ph.D. Thesis. The George Washington University, $\quad$ DC, 2013. http://gradworks.umi.com/35/57/3557518.html (accessed March 2016).

[37]H. Xu, R. Yuro, I. Harrison, The structure and corrosion chemistry of bromine on Pt(111), Surf. Sci. 411 (1998) 303.

[38] O. Baturina, K. Swider-Lyons, Effect of $\mathrm{SO}_{2}$ on the performance of the cathode of a PEM fuel cell at 0.5-0.7 V, J. Electrochem. Soc. 156 (2009) B1423. 


\section{Figure captions:}

Figure 1: Cell voltage responses to 20-ppm bromomethane in the airstream of PEMFCs holding at a constant current of $1 \mathrm{~A} \mathrm{~cm}^{-2}$ at $45{ }^{\circ} \mathrm{C}$ for 8 and $30 \mathrm{~h}$ and then exposed to neat air for recovery. The chlorobenzene result (with 20-ppm $\mathrm{C}_{6} \mathrm{H}_{5} \mathrm{Cl}$ in air) is reproduced here for comparison [29]. (Colors online)

Figure 2: (a) EIS before, during and after the $30 \mathrm{~h}$ 20-ppm bromomethane contamination as shown in Figure 1; and (b) the variation in Ro, Ra, Rc and Rd. (Colors online)

Figure 3: (a) Cathode, Ec, (b) anode, Ea CV profiles, and (c) ECSA of the MEAs before (BOT) and after (EOT) the $8 \mathrm{~h}$ and $30 \mathrm{~h}$ 20-ppm bromomethane contamination experiments as shown in Figure 1. The results of the 20-ppm chlorobenzene contamination experiments are shown as a reference. (Colors online)

Figure 4: LSV curves before exposure (BOT) and after the 20-ppm bromomethane exposure followed by neat air recovery (EOT). (Colors online)

Figure 5: MEA polarization curves before exposure (BOT) and after the 20-ppm bromomethane exposure followed by neat air recovery (EOT). Inset highlights the difference in the kinetic region. (Colors online)

Figure 6. Pt LIII edge of in situ spectro-electrochemical cell of a fresh CCM at OCV conditions, the same CCM at $0.6 \mathrm{~V}$, and again at $0.6 \mathrm{~V}$ after 40 -min exposure to 500-ppm bromomethane in air. (Colors online)

Figure $7 \Delta \mu$ at $0.6 \mathrm{~V}$ after exposure to 500-ppm bromomethane in air. The theoretical $\Delta \mu_{\text {theo }}$ as obtained from FEFF8 calculations on a $\mathrm{Pt}_{6}$ cluster with $\mathrm{Br}$ adsorbed in an atop site is also shown. The theoretical curve has a different $\Delta \mu$ scale and is offset by a value of 0.45 versus the measured curve. (Colors online) 
Figure 8 a) Illustration of the possible pathway of bromomethane access to Pt electrode; and b) adsorption of bromomethane and chlorobenzene on the cathode catalyst of a PEMFC. PZC: point of zero charge. (Colors online) 


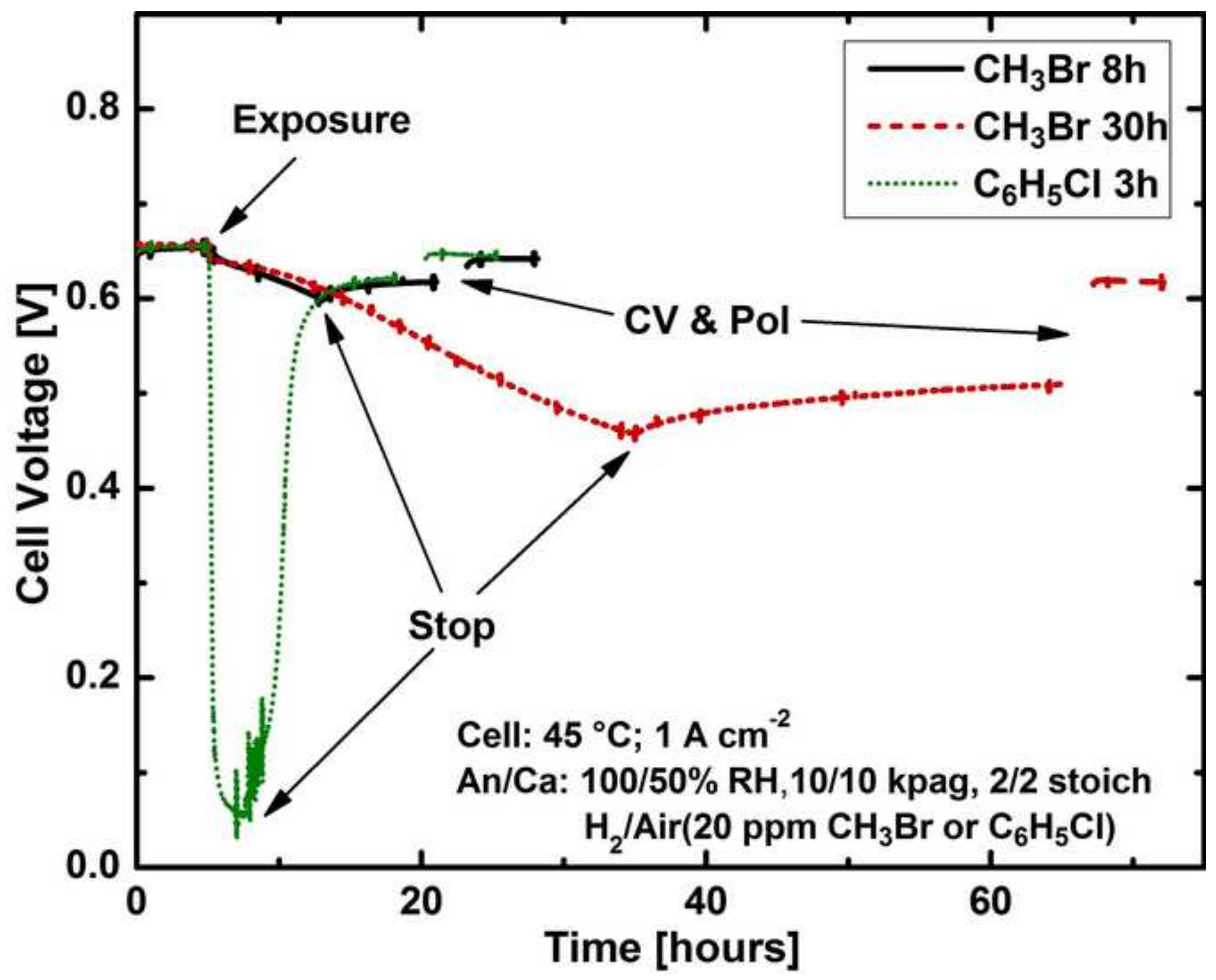




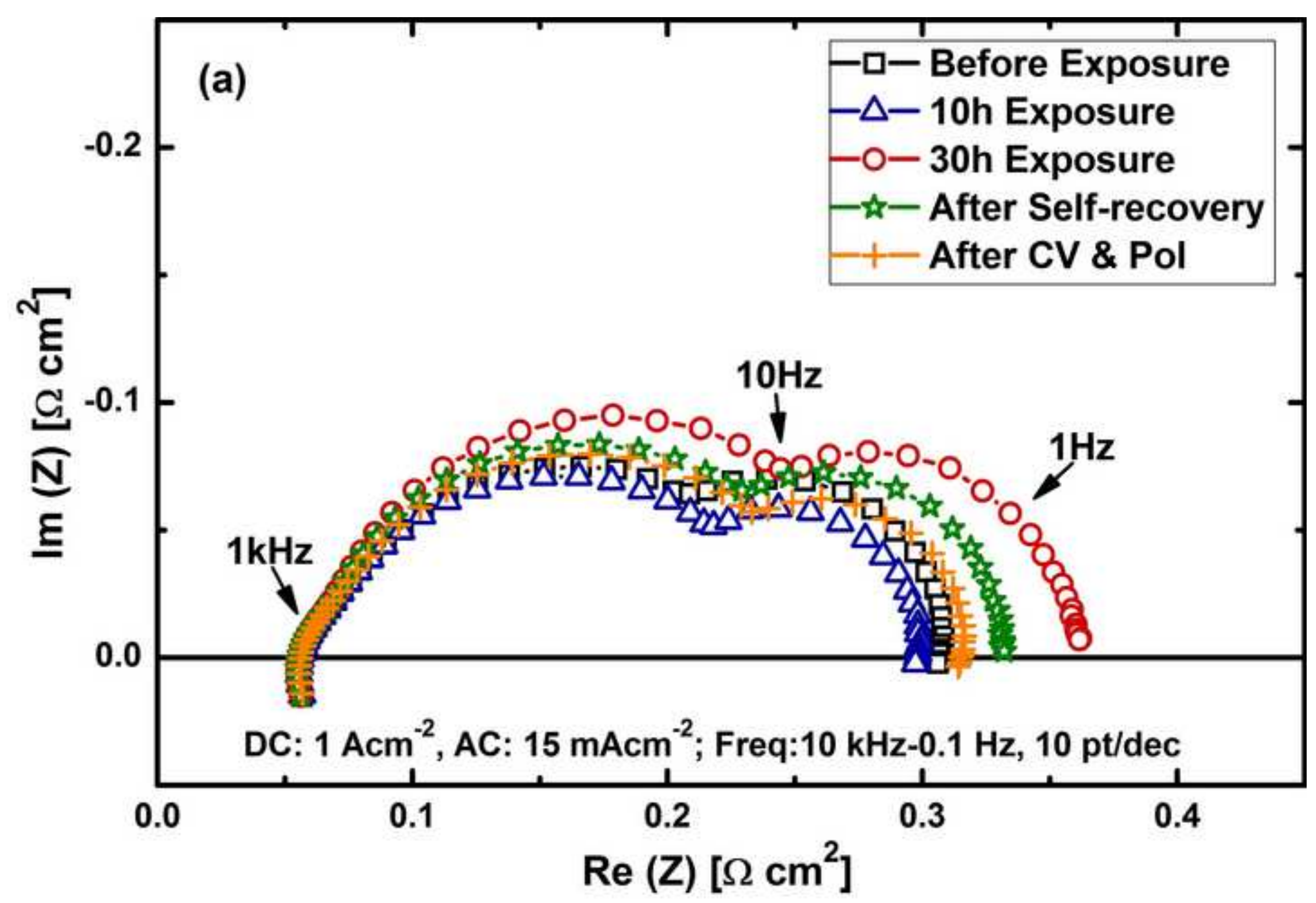




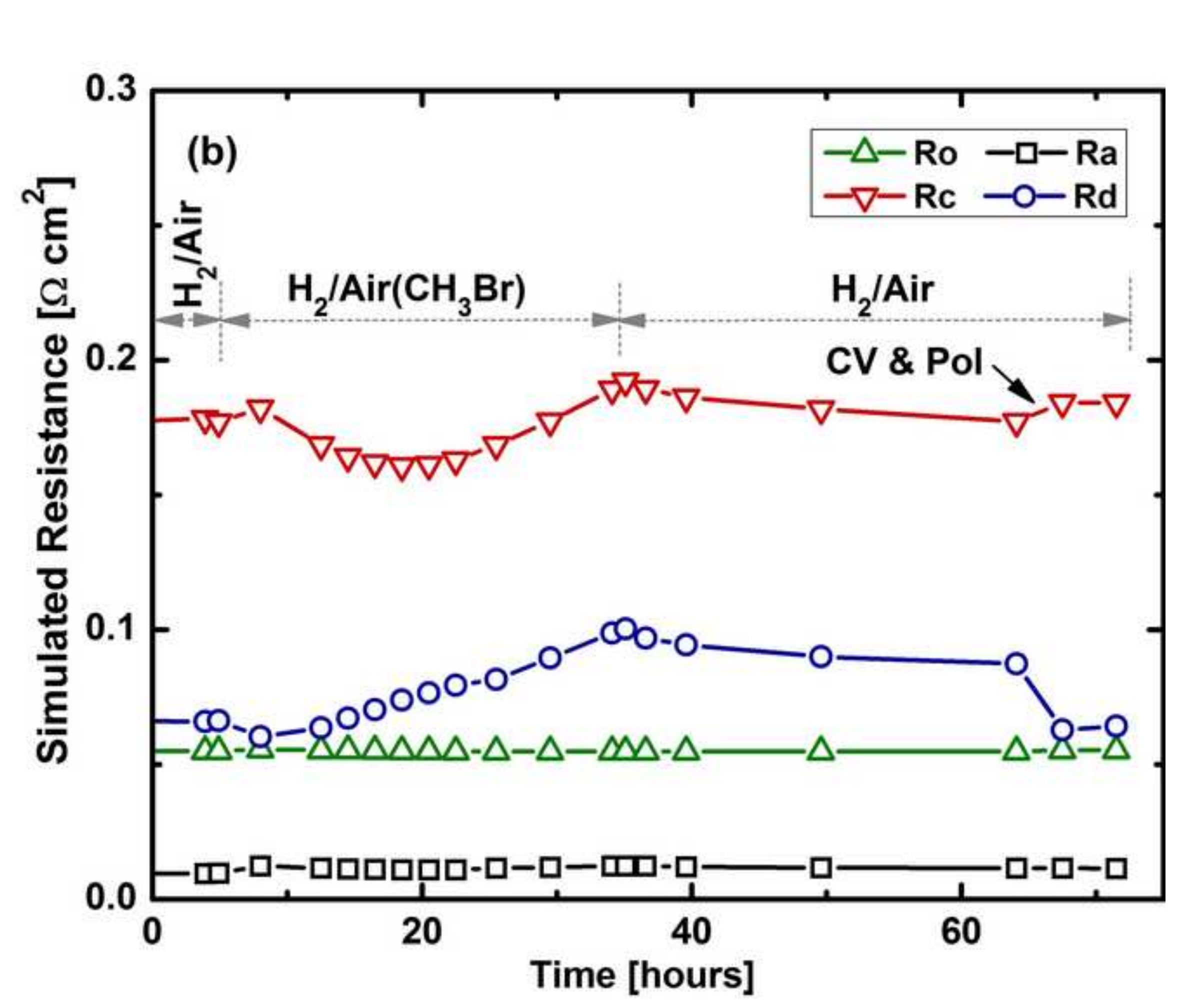




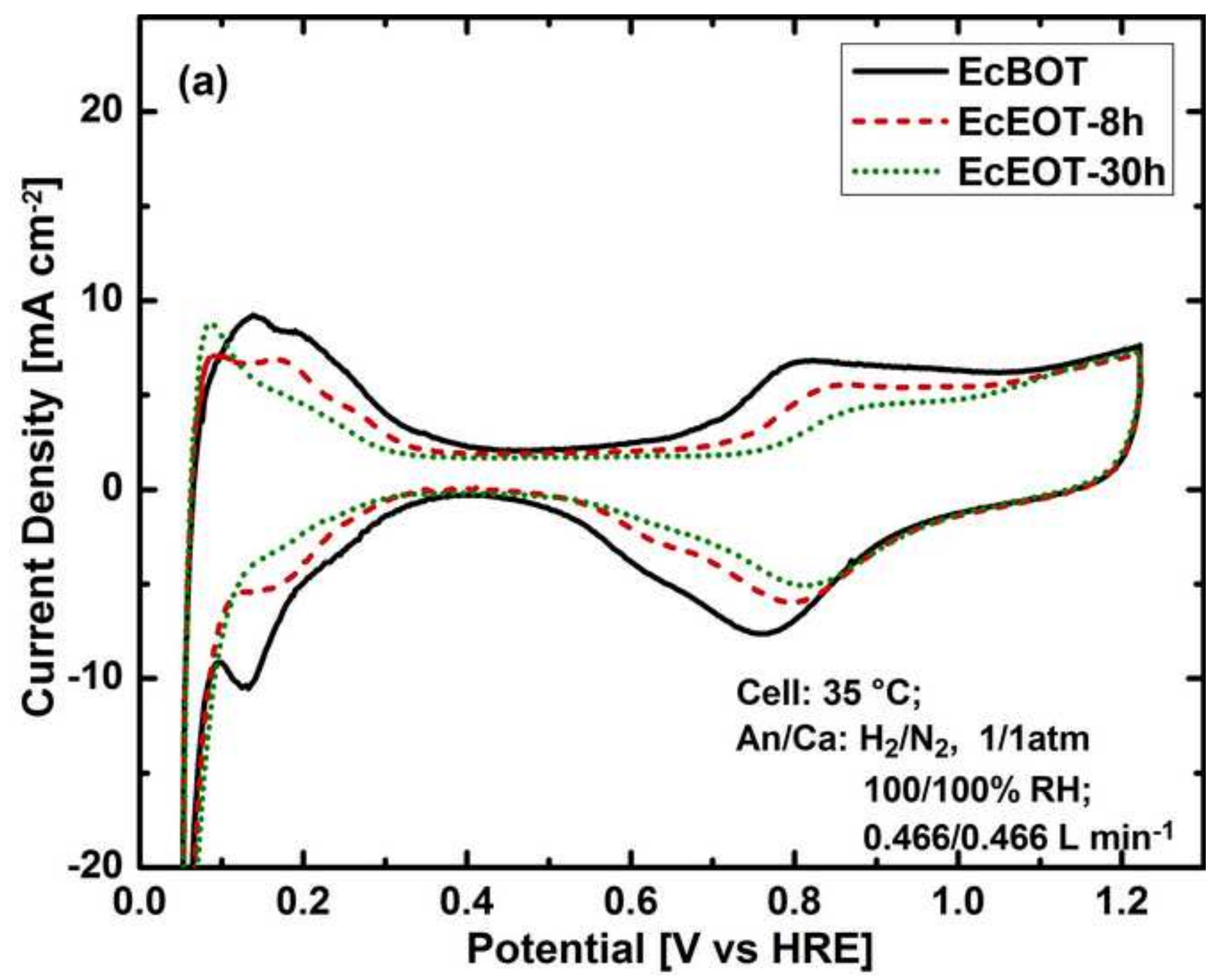




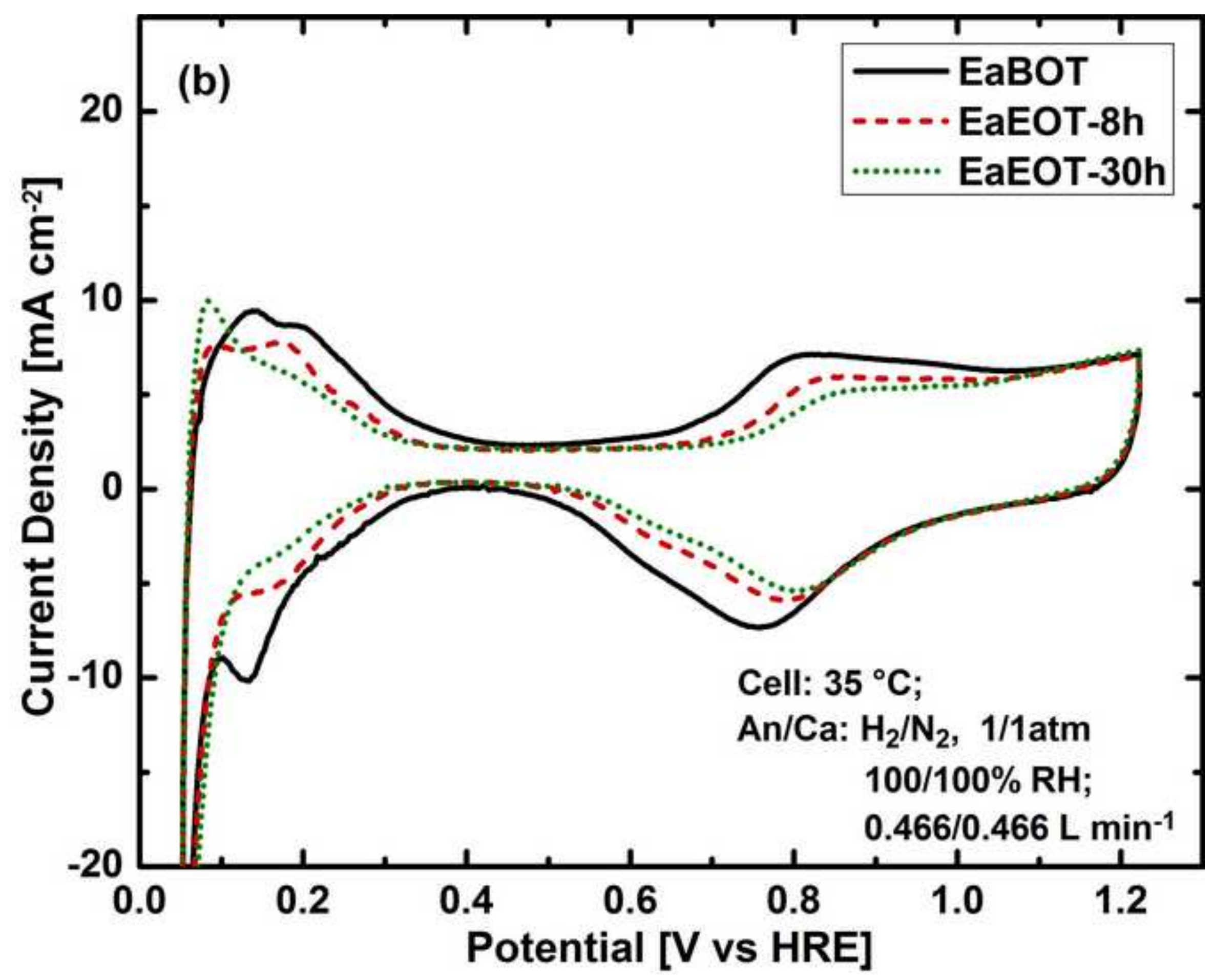




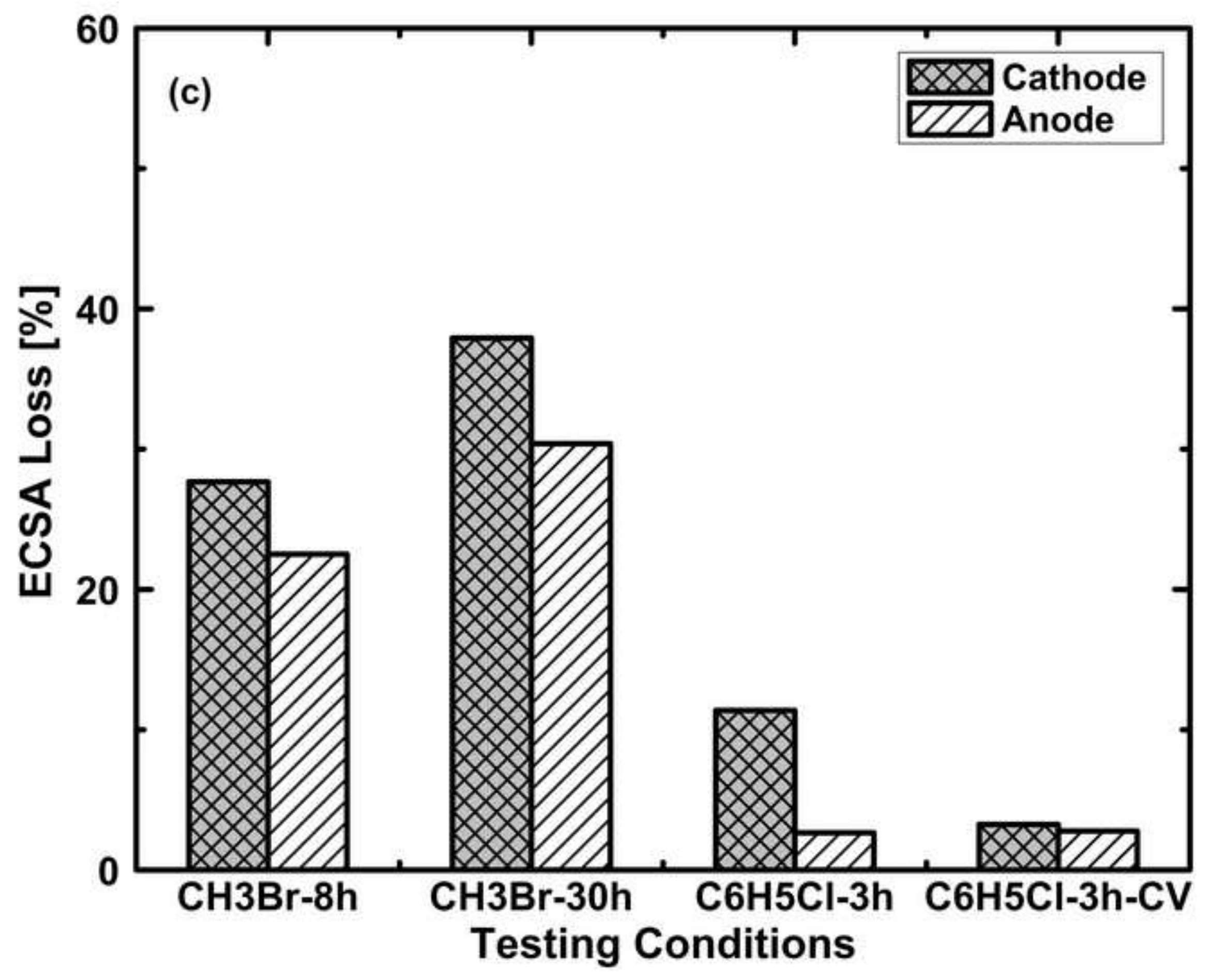




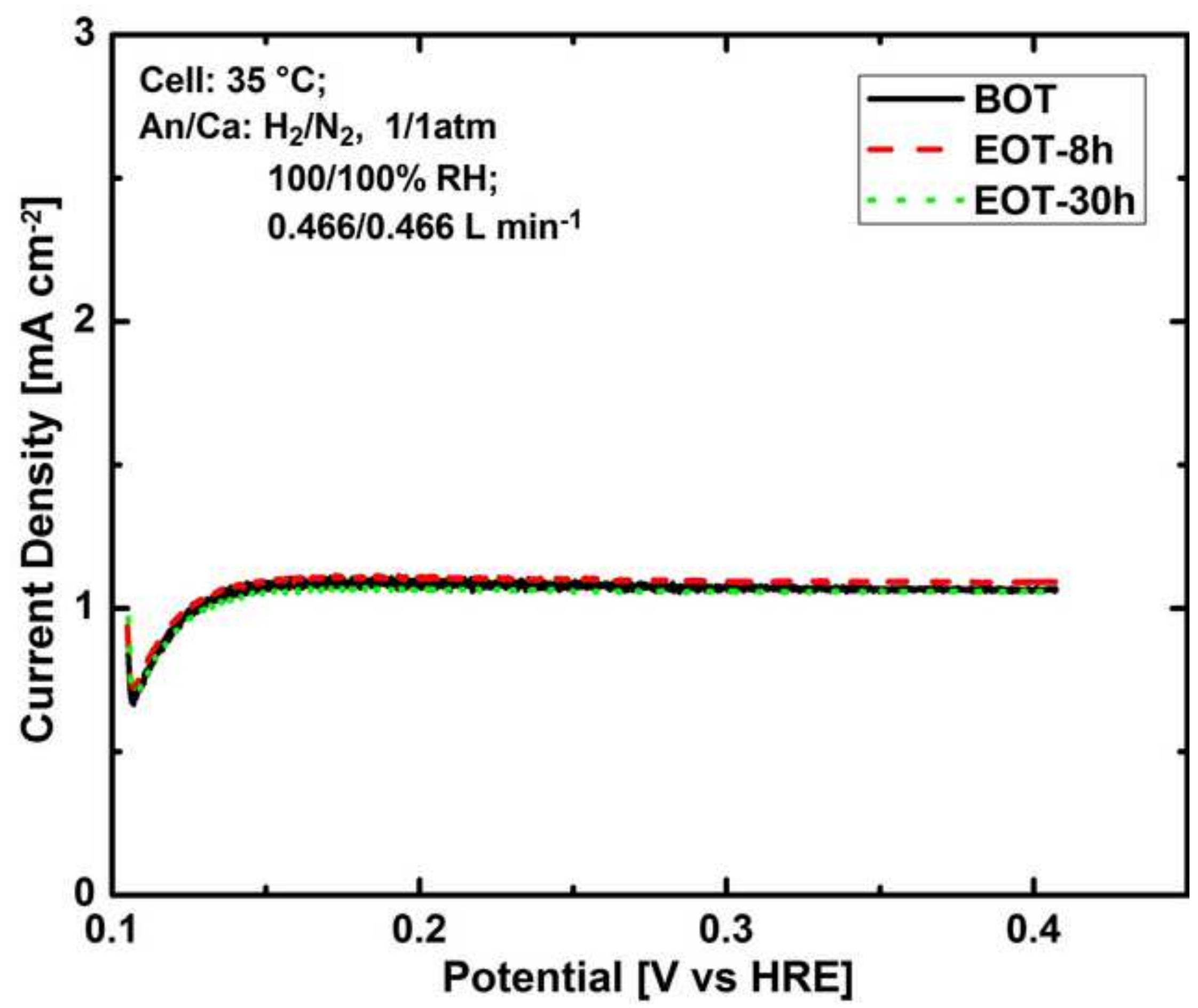




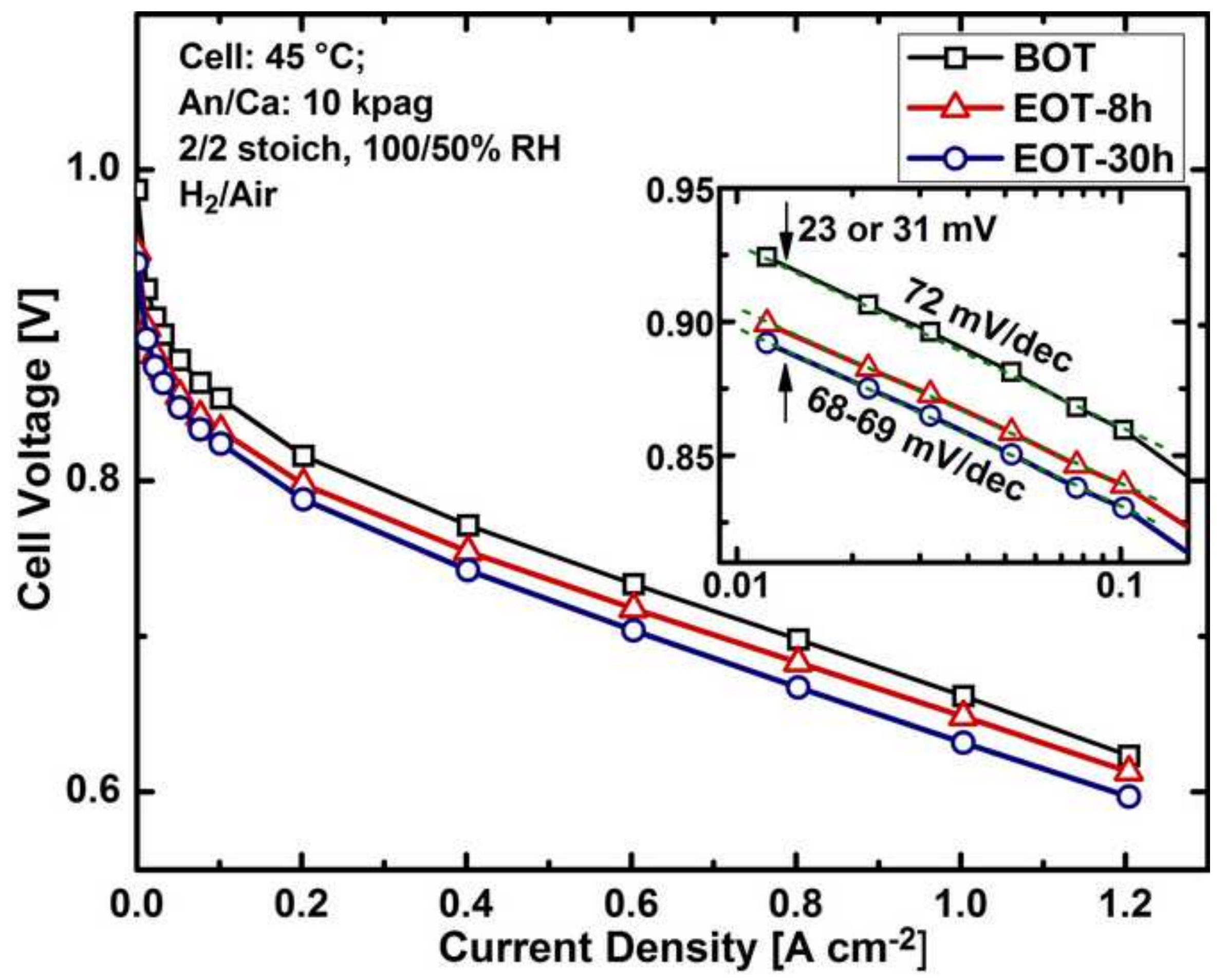




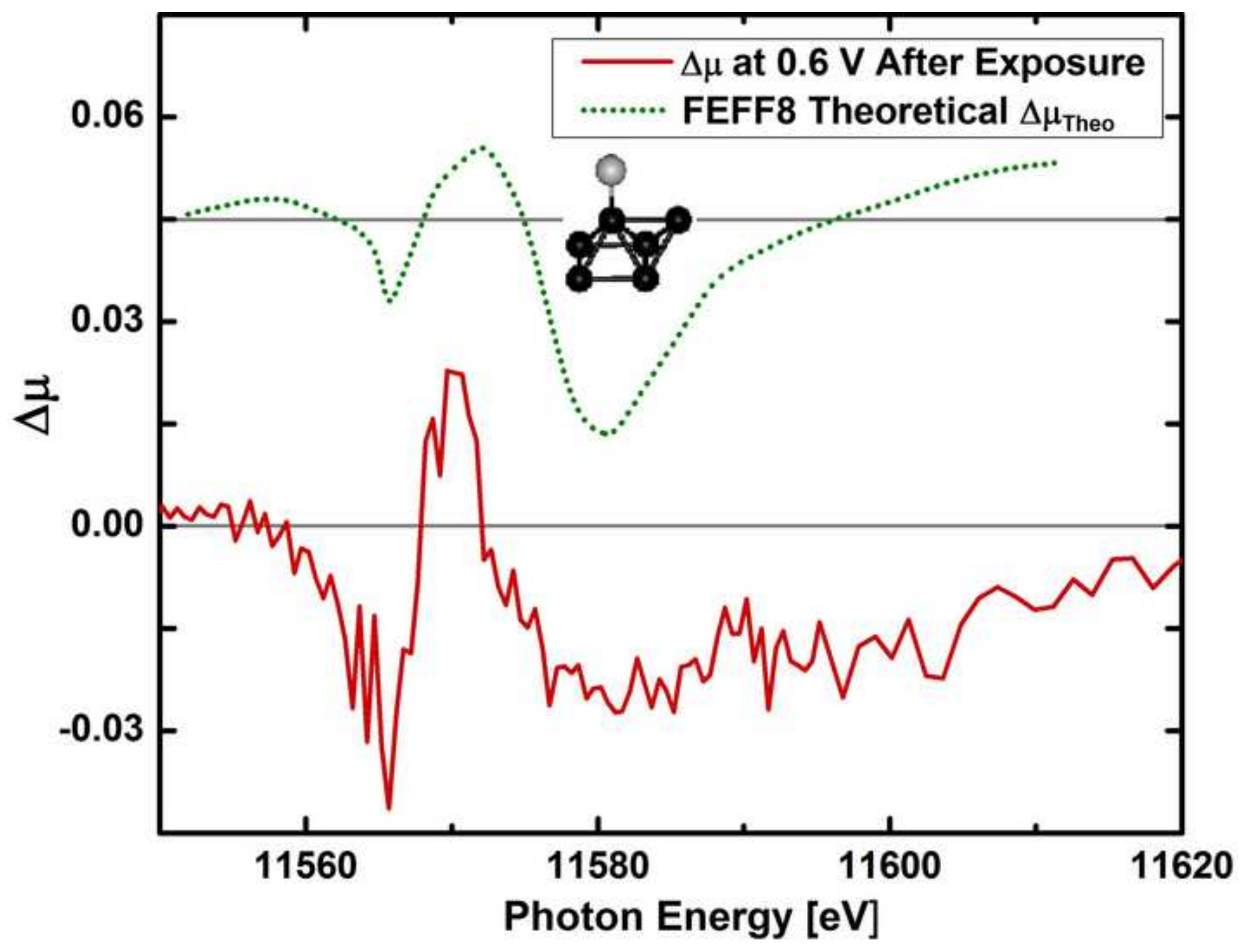

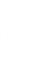
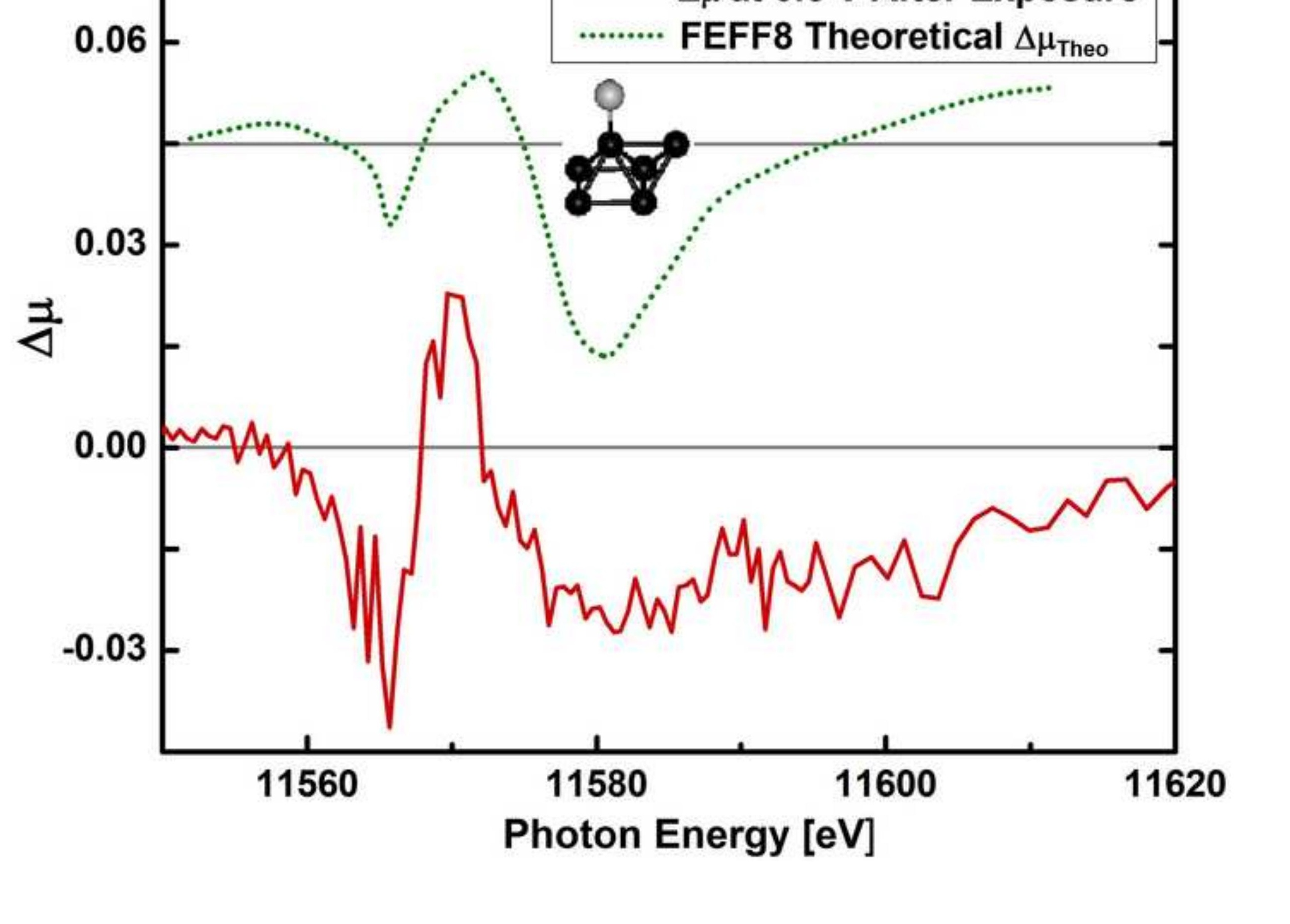


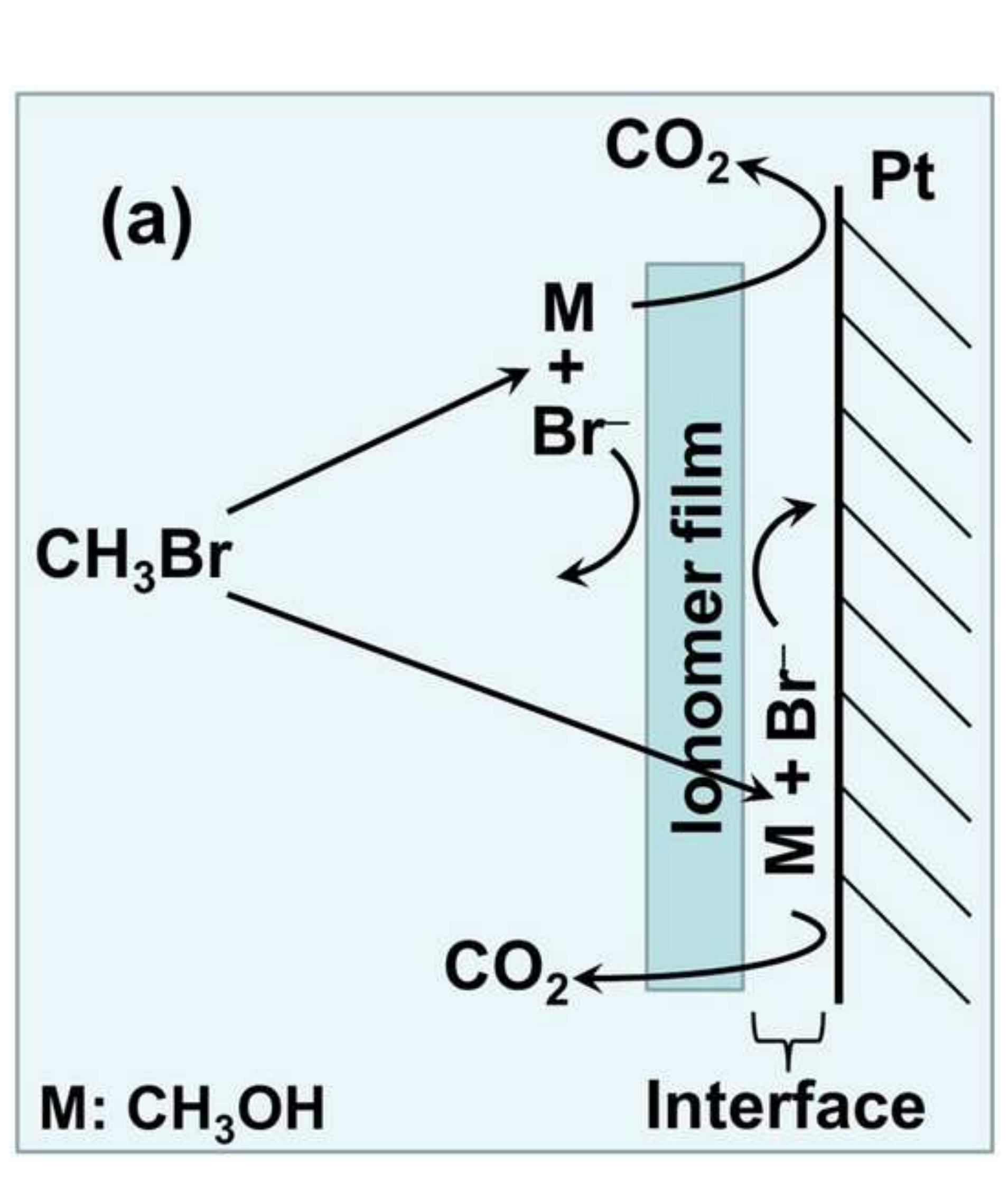

Figure(s) 


\section{Bromomethane}

\section{Chlorobenzene}
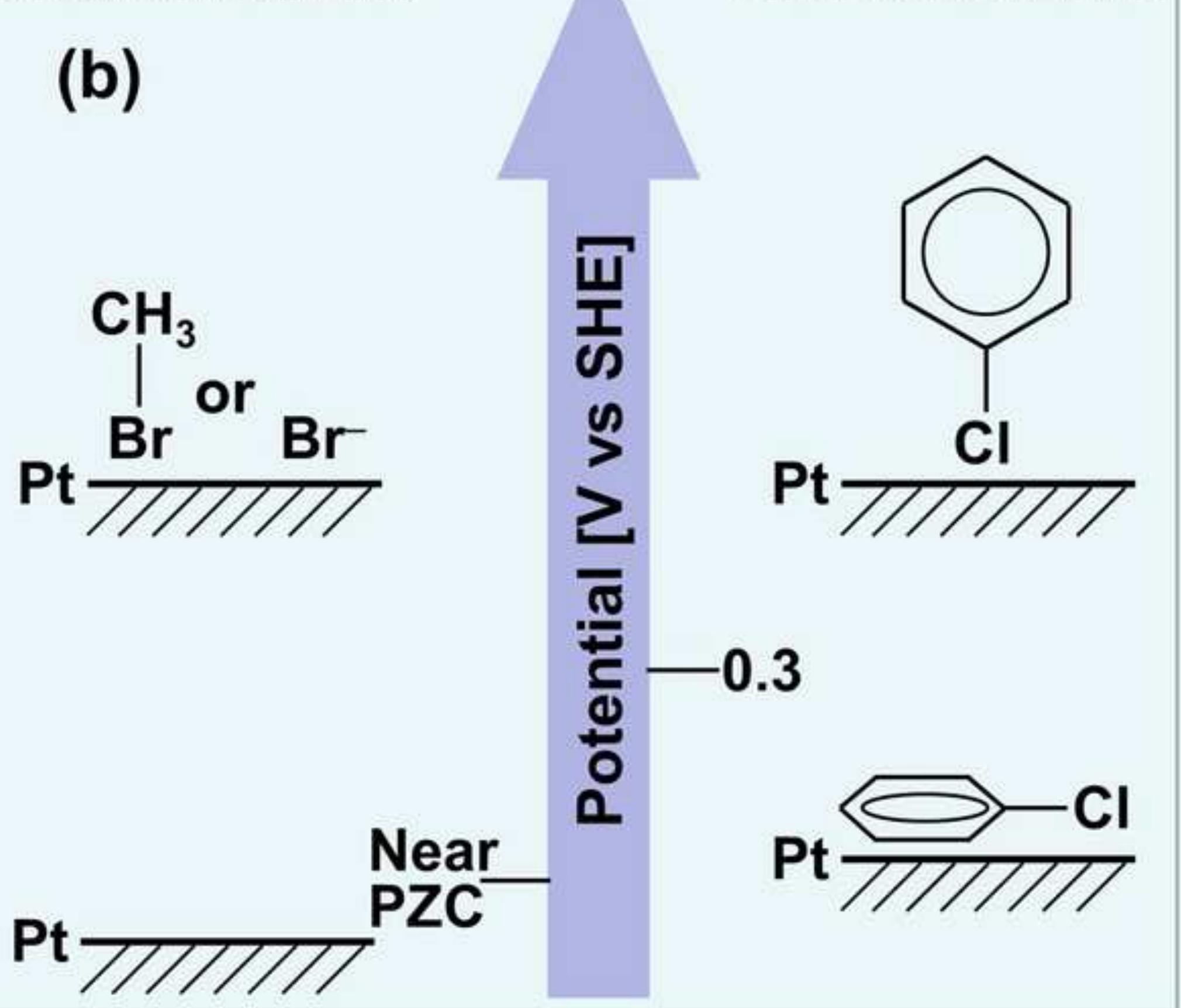